\title{
Vibrio gallicus sp. nov., isolated from the gut of the French abalone Haliotis tuberculata
}

Correspondence
Tomoo Sawabe
sawabe@fish.hokudai.ac.jp

\author{
Tomoo Sawabe, ${ }^{1}$ Karin Hayashi, ${ }^{1}$ Jun Moriwaki, ${ }^{1}$ Fabiano L. Thompson, ${ }^{2}$ \\ Jean Swings, ${ }^{2}$ Philippe Potin, ${ }^{3}$ Richard Christen ${ }^{4}$ and Yoshio Ezura ${ }^{1}$ \\ ${ }^{1}$ Laboratory of Microbiology, Graduate School of Fisheries Sciences, Hokkaido University, \\ 3-1-1 Minato-cho, Hakodate 041, Japan \\ ${ }^{2}$ Laboratory of Microbiology, University of Ghent, Ledeganckstraat 35, B-9000 Ghent, Belgium \\ 3UMR 1931 CNRS/Goëmar, Place Georges Teissier B.P. 74, F29682 Roscoff cedex, France \\ ${ }^{4}$ UMR 6543 CNRS - Université de Nice Sophia Antipolis, Centre de Biochimie, Parc Valrose, \\ F06108 Nice cedex 2, France
}

Vibrio halioticoli and a phylogenetically related species (Vibrio superstes), which are alginolytic, non-motile, fermentative, marine bacteria, are commonly found in the gut of Haliotis abalones in Japan (Sawabe et al., 1995, 2002), South Africa (Sawabe et al., 2003) and Australia (Hayashi et al., 2003). The hypothesized roles of $V$. halioticoli include its contribution to the digestion of alginate, which is a major polysaccharide in Japanese and South African kelps that is ingested by these animals, and its conversion into volatile short-chained fatty acids via fermentation (Sawabe et al., 2003). On the other hand, V. superstes may play a minor role in Australian abalone, due to a small population in the gut of the abalone (Hayashi et al., 2003).

Published online ahead of print on 12 December 2003 as DOI 10.1099/ijs.0.02804-0.

Abbreviations: FAFLP, fluorescence amplified fragment length polymorphism; ML, maximum-likelihood; MP, maximum-parsimony; NJ, neighbour-joining.

The GenBank/EMBL/DDBJ accession numbers for the 16S rRNA gene sequences of $V$. gallicus are AY257972 (CIP 107863 ${ }^{\top}=\mathrm{LMG}$ $21878^{\top}=$ strain $\mathrm{HT} 2-^{\top}$ ), AY257971 (CIP 107864=strain HT1-3), AY257973 (CIP 107865=strain HT1-12), AY257974 (CIP $107866=$ strain HT2-6) and AY257975 (CIP $107867=$ strain HT3-3).

A table of phenotypic characteristics is available as supplementary material in IJSEM Online.
We have examined the presence of $V$. halioticoli-like bacteria in the gut of abalones; recently, we isolated a set of five strains, which were most similar phenotypically to $V$. halioticoli, from the gut of French abalones (Haliotis tuberculata). DNA-DNA hybridization experiments, phenotypic characterization and phylogenetic and genetic analyses demonstrated that these strains represent a so far unknown species of the genus Vibrio.

Five strains of Vibrio gallicus sp. nov. (CIP $107863^{\mathrm{T}}=\mathrm{LMG}$ $21878^{\mathrm{T}}=\mathrm{HT} 2-1^{\mathrm{T}}$, LMG $21329=\mathrm{CIP} 107864=\mathrm{HT} 1-3$, CIP $107865=$ HT1-12, CIP $107866=$ HT2-6 and CIP $107867=$ HT3-3) were isolated from the gut of French abalones (H. tuberculata). These were collected at the coastal area of Brest (Brittany, France) by Scuba diving in February 2001. Strains were cultured on ZoBell 2216E agar (Oppenheimer \& ZoBell, 1952) and stored at $-80{ }^{\circ} \mathrm{C}$ in ZoBell broth that contained $10 \%$ glycerol.

About $1400 \mathrm{bp}$ of the $16 \mathrm{~S}$ rRNA gene sequences for strains CIP $107863^{\mathrm{T}}$, CIP 107864, CIP 107865, CIP 107866 and CIP 107867 was determined according to Sawabe et al. (1998), by using six sequence primers (24F, 530F, 1100F, 520R, 920R and 1540R). Sequences of $V$. gallicus CIP $107863^{\mathrm{T}}$, CIP 107864, CIP 107865, CIP 107866 and CIP 107867 were used for phylogenetic analyses. The $16 \mathrm{~S}$ rRNA gene sequences of $V$. gallicus were used in a BLAST search of GenBank/EMBL 
and NRupdates (28 July 2003), in order to retrieve the 50 most closely related sequences. New sequences were included and aligned in a local database of 85000 already aligned bacterial $16 \mathrm{~S}$ rRNA gene sequences. Selection of sequences for the final analysis was according to previous phylogenetic analyses of the entire database and the results of the BLAST query. Thirty-one sequences were retained, excluding unidentified species and non-type species. Phylogenetic trees were constructed by using three different methods [BIONJ (neighbour-joining), maximum-likelihood (ML) and maximum-parsimony (MP)]. For neighbourjoining $(\mathrm{NJ})$ analysis, distance matrices were calculated by using the Kimura two-parameter correction. BIONJ was according to Gascuel (1997) and ML and MP were from PHYLIP (Phylogeny Inference Package, version 3.573c; distributed by J. Felsenstein, Department of Genetics, UW, Seattle, WA, USA). For the final tree, almost-entire sequences (corresponding to positions 67-1401 of the type strain of $V$. gallicus) were used (parts of sequences that were available for all strains and showed no obvious homoplasy). Phylogenetic trees were drawn by using NJPLOT (Perrière \& Gouy, 1996). When several sequences were available for a type species, all sequences were included in a preliminary analysis (they often differed by a few nucleotides) and a single one was chosen for the tree that is presented. The distance bar in Fig. 1 corresponds to distances that were corrected as indicated above and has no meaning in terms of sequence similarities.

The results of our phylogenetic analysis showed clearly that the new strains belong to the $\gamma 3$ subgroup of the $\gamma$ Proteobacteria (Garrity \& Holt, 2000). The closest phylogenetic neighbours of the five French abalone strains were species such as $V$. halioticoli, V. superstes, Vibrio fischeri and a number of other species, as shown in Fig. 1, but no single known species could be grouped significantly with $V$. gallicus in a robust clade. The five strains of $V$. gallicus had $98.0 \%$ or less $16 \mathrm{~S}$ rRNA gene sequence similarity with
$V$. superstes LMG $21323^{\mathrm{T}}, 97 \cdot 8 \%$ with $V$. halioticoli IAM $14596^{\mathrm{T}}, 97 \cdot 2 \%$ with Vibrio agarivorans and $97 \cdot 1 \%$ or less with Vibrio penaeicida, but none of these species was a sister species to V. gallicus. All other Vibrio species, including V. fischeri, Vibrio salmonicida, Vibrio logei and Vibrio wodanis (sister species), showed similarity levels of $<97 \%$. Phylogenetic analysis of $16 \mathrm{~S}$ rRNA gene sequences demonstrates clearly that the five new strains belong to the genus Vibrio and suggests that they should be assigned to a novel species, as they do not form a robust clade with any single recognized Vibrio species.

In total, 78 phenotypic characteristics of $V$. gallicus, $V$. halioticoli, V. superstes and V. fischeri strains were determined as described previously (Leifson, 1963; Hidaka \& Sakai, 1968; West et al., 1977; Ostle \& Holt, 1982; Baumann \& Schubert, 1984; Holt et al., 1994). Phenotypic characterization was done under the same conditions at $20^{\circ} \mathrm{C}$. All available phenotypic traits of sister species ( $V$. salmonicida, $V$. logei and $V$. wodanis) and V. agarivorans (Baumann \& Schubert, 1984; Egidius et al., 1986; Lunder et al., 2000; Macián et al., 2001) were compared to those of V. gallicus.

The five French abalone strains have the main phenotypic features of the genus Vibrio (except for the absence of flagella). The strains are non-motile, Gram-negative and fermentative (Sawabe et al., 1998). No flagellated cells were observed by transmission electron microscopic observations. These strains require salt for their growth, do not accumulate poly- $\beta$-hydroxybutyrate and are oxidasepositive (see Supplementary Table, available in IJSEM Online). No peritrichous cells were observed when the strains were cultivated on solid media. Other phenotypic features of $V$. gallicus are shown in the Supplementary Table (available in IJSEM Online). The mesophilic growth temperature of $V$. gallicus is a key phenotypic trait that differentiates it from its psychrophilic sister species $V$. salmonicida, $V$. logei and $V$. wodanis. The five abalone

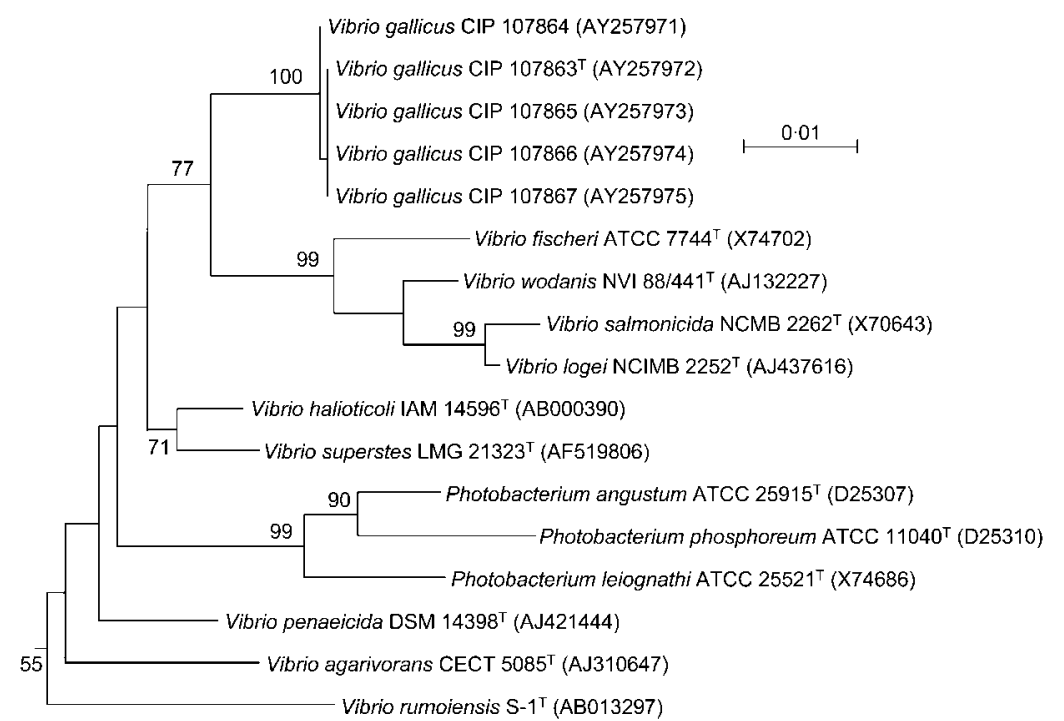

Fig. 1. Rooted phylogenetic tree based on 16S rRNA gene sequence data. This figure combines the results of three analyses, i.e. NJ, MP and ML. The topology shown was obtained by using NJ. Bootstrap values (percentages of 1000 replicates) are shown only for branches that were also obtained in $\mathrm{ML}$ analysis $(P<0.01$; In likelihood, $-4700 \cdot 67781$; 3675 trees examined) and in the strict consensus tree of 39 most parsimonious trees. Branches with percentages can thus be considered as robust. 
isolates were most similar phenotypically to $V$. halioticoli IAM $14596^{\mathrm{T}}$, although the strains differed by four traits out of 78 tested (see Supplementary Table, available in IJSEM Online).

DNA of bacterial strains was prepared by using a Promega Wizard DNA extraction kit for fluorescence amplified fragment length polymorphism (FAFLP) analysis, and by the procedures of Marmur (1961) for measurement of $\mathrm{G}+\mathrm{C}$ content and DNA hybridization experiments. FAFLP analysis was performed as described previously (Thompson et al., 2001; Sawabe et al., 2002). Clustering of the patterns was done by using the Dice coefficient $\left(S_{\mathrm{D}}\right)$ and the Ward algorithm (Sneath \& Sokal, 1973). DNA G +C contents were determined by HPLC (Tamaoka \& Komagata, 1984). DNA-DNA hybridization experiments were performed in microdilution wells by using a fluorometric direct binding method, as described by Ezaki et al. (1988, 1989). DNA homology values are indicated as means of triplicate measurements.

FAFLP patterns of V. gallicus CIP $107863^{\mathrm{T}}$ and CIP 107864 consisted respectively of 87 and 103 bands. The similarity between these two band patterns was $79 \%$ (Fig. 2). The FAFLP pattern similarity of $V$. gallicus to $V$. halioticoli, Vibrio rumoiensis and Vibrio harveyi was 48,47 and $44 \%$, respectively. FAFLP pattern similarity of CIP $107863^{\mathrm{T}}$ and CIP 107864 to other Vibrio species, including the sister species of $V$. gallicus ( $V$. wodanis, $V$. logei and $V$. salmonicida), was $<44 \%$, indicating clearly that this

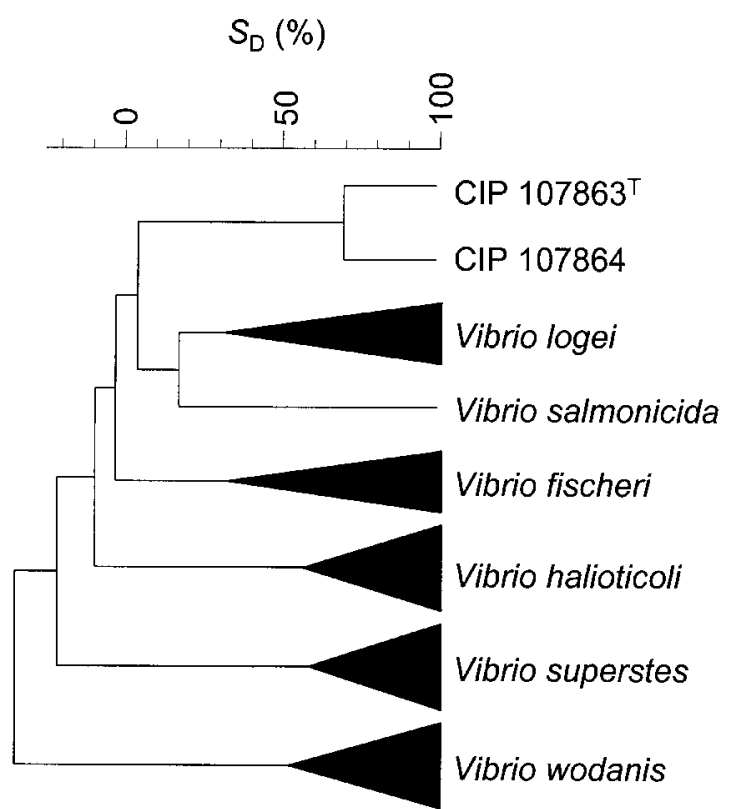

Fig. 2. Dendrogram based on the FAFLP band patterns of Vibrio gallicus (CIP $107863^{\top}$ and CIP 107864) and its closest phylogenetic neighbours, using the Dice coefficient $\left(S_{D}\right)$, the Ward algorithm and a band position tolerance of $0.2 \%$. novel species is different from other vibrios (Thompson et al., 2001). The FAFLP results are supported by our DNA-DNA hybridization experiments, which showed that the five strains of $V$. gallicus, CIP $107863^{\mathrm{T}}$, CIP 107864, CIP 107865, CIP 107866 and CIP 107867, were conspecific strains that were clearly separate from $V$. halioticoli, V. superstes, V. fischeri, V. agarivorans and V. logei (See Supplementary Table in IJSEM Online).

In conclusion, our polyphasic study demonstrates clearly that the five abalone isolates represent a so far undescribed species of the genus Vibrio, for which we propose the name Vibrio gallicus sp. nov. This study also reveals the fourth finding of the presence of $V$. halioticoli-related bacteria in the gut of abalones. As $V$. gallicus is a major component ( $>50 \%$ ) of the gut microflora of the French abalone, a symbiotic association between $V$. gallicus and French abalone is also hypothesized.

We have found three species of vibrios, $V$. halioticoli, $V$. superstes and V. gallicus, that are associated with abalone. These species are related phylogenetically (Fig. 1), but are different phenotypically (see Supplementary Table, available in IJSEM Online). The ecological niches of these species are similar (Sawabe et al., 1998, 2003; Hayashi et al., 2003). A recent phylogenetic study that used internal transcribed spacer region sequences of 19 species of the genus Haliotis (Coleman \& Vacquier, 2002) revealed three subclades in the genus, each encompassing low variation. North Pacific species group together, whereas Australian and European species are different subclades. A single species, Haliotis iris from New Zealand, is quite distant from the remaining species of Haliotis. Haliotis midae and Haliotis diversicolor supertexta (Taiwan) both diverged basal to European and Australian species. Assuming coevolution of the symbiotic relationships between vibrios and Haliotis species, the taxonomic status of $V$. gallicus and $V$. superstes as close relatives of $V$. halioticoli is in accordance with the phylogeny of Haliotis species. Comparative whole-genome analyses among these three species are needed to clarify the evolutionary history. Ecological studies of $V$. gallicus are also needed, in order to better understand its interactions in the gut of marine herbivores, particularly abalones.

\section{Description of Vibrio gallicus sp. nov.}

Vibrio gallicus (gal'li.cus. L. masc. adj. gallicus from France).

Gram-negative, facultatively anaerobic, non-motile and non-flagellated. Cells in ZoBell $2216 \mathrm{E}$ broth are rodshaped with rounded ends $(0.5-0.6 \times 1 \cdot 2-3.0 \mu \mathrm{m})$. No endospores or capsules are formed. Flagellation is not observed when the organism is cultivated on solidified media and/or in liquid media. Colonies on ZoBell 2216E agar are beige, circular, smooth and convex with an entire edge. Sodium ions are essential for growth. Mesophilic and neutrophilic chemo-organotroph that grows at temperatures between 15 and $30^{\circ} \mathrm{C}$. No growth occurs at 
$37^{\circ} \mathrm{C}$. Positive for acid production from glucose, nitrate reduction, hydrolysis of alginate, oxidase and catalase and assimilation of D-fructose, D-glucose, maltose, D-mannitol and alginate. The following tests are negative: gas production from glucose, acetoin production, lysine decarboxylase, ornithine decarboxylase, arginine dehydrolase, $\beta$-galactosidase test, luminescence, pigmentation, requirement for organic growth factors, hydrolysis of starch, gelatin, chitin, Tween 80 and agar, accumulation of poly$\beta$-hydroxybutyrate, assimilation of D-mannose, sucrose, D-gluconate, D-sorbitol, 2-oxoglutarate, D-galactose, cellobiose, melibiose, lactose, D-glucuronate, trehalose, putrescine, $\gamma$-aminobutyrate, acetate, pyruvate, L-tyrosine, propionate, D-glucosamine, fumarate, succinate, meso-erythritol, D-xylose, L-arabinose, citrate, DL-malate, $\delta$-aminovarate and aconitate. DNA G + C content is $43 \cdot 6-44 \cdot 3 \mathrm{~mol} \%$.

The type strain is CIP $107863^{\mathrm{T}}=\mathrm{LMG} 21878^{\mathrm{T}}$. Isolated from the gut of the French abalone Haliotis tuberculata.

\section{Acknowledgements}

This work was supported by Grants-in-Aid for Scientific Research from the Ministry of Education, Science and Culture of Japan (nos 09460081 and 13760134) and F. L. T. has a PhD scholarship (no. 2008361/98-6) from Conselho Nacional de Desenvolvimento Científico e Tecnológico (CNPq), Brazil. J.S. acknowledges grants from the Fund for Scientific Research (FWO), Belgium. We gratefully thank Dr Bernard Kloareg, Station Biologique (CNRS/Goëmar), for helpful discussion and critical reading. This work was also supported by funds from the European Commission for the AQUA-CHIP project (OLK4-2000-00764). The authors are solely responsible for the content of this publication. It does not represent the opinion of the European Commission. The European Commission is not responsible for any use that might be made of data appearing therein.

\section{References}

Baumann, P. \& Schubert, R. H. W. (1984). Vibrionaceae. In Bergey's Manual of Systematic Bacteriology, vol. 1, pp. 516-550. Edited by N. R. Krieg \& J. G. Holt. Baltimore: Williams \& Wilkins.

Coleman, A. W. \& Vacquier, V. D. (2002). Exploring the phylogenetic utility of ITS sequences for animals: a test case for abalone (Haliotis). J Mol Evol 54, 246-257.

Egidius, E., Wiik, R., Andersen, K., Hoff, K. A. \& Hjeltnes, B. (1986). Vibrio salmonicida sp. nov., a new fish pathogen. Int J Syst Bacteriol 36, 518-520.

Ezaki, T., Hashimoto, Y., Takeuchi, N., Yamamoto, H., Liu, S.-L., Miura, H., Matsui, K. \& Yabuuchi, E. (1988). Simple genetic method to identify viridans group streptococci by colorimetric dot hybridization and fluorometric hybridization in microdilution wells. J Clin Microbiol 26, 1708-1713.

Ezaki, T., Hashimoto, Y. \& Yabuuchi, E. (1989). Fluorometric deoxyribonucleic acid-deoxyribonucleic acid hybridization in microdilution wells as an alternative to membrane filter hybridization in which radioisotopes are used to determine genetic relatedness among bacterial strains. Int J Syst Bacteriol 39, 224-229.

Garrity, G. M. \& Holt, J. G. (2000). The road map to the Manual. In Bergey's Manual of Systematic Bacteriology, 2nd edn, vol. 1, pp. 119-166. Edited by D. R. Boone, R. W. Castenholz \& G. M. Garrity. New York: Springer.
Gascuel, O. (1997). BIONJ: an improved version of the NJ algorithm based on a simple model of sequence data. Mol Biol Evol 14, 685-695.

Hayashi, K., Moriwaki, J., Sawabe, T., Thompson, F. L., Swings, J., Gudkovs, N., Christen, R. \& Ezura, Y. (2003). Vibrio superstes sp. nov., isolated from the gut of Australian abalones Haliotis laevigata and Haliotis rubra. Int J Syst Evol Microbiol 53, 1813-1817.

Hidaka, T. \& Sakai, M. (1968). Comparative observation of inorganic salt requirement of the marine and terrestrial bacteria. Bull Misaki Mar Biol Inst Kyoto Univ 12, 125-149.

Holt, J. G., Krieg, N. R., Sneath, P. H. A., Staley, J. T. \& Williams, S. T. (1994). Facultatively anaerobic Gram-negative rods. Subgroup 2: family Vibrionaceae. In Bergey's Manual of Determinative Microbiology, 9th edn, pp. 190-253. Baltimore: Williams \& Wilkins.

Leifson, E. (1963). Determination of carbohydrate metabolism of marine bacteria. J Bacteriol 85, 1183-1184.

Lunder, T., Sørum, H., Holstad, G., Steigerwalt, A. G., Mowinckel, P. \& Brenner, D. J. (2000). Phenotypic and genotypic characterization of Vibrio viscosus sp. nov. and Vibrio wodanis sp. nov. isolated from Atlantic salmon (Salmo salar) with 'winter ulcer'. Int J Syst Evol Microbiol 50, 427-450.

Macián, M. C., Ludwig, W., Schleifer, K. H., Pujalte, M. J. \& Garay, E. (2001). Vibrio agarivorans sp. nov., a novel agarolytic marine bacterium. Int J Syst Evol Microbiol 51, 2031-2036.

Marmur, J. (1961). A procedure for the isolation of deoxyribonucleic acid from microorganisms. J Mol Biol 3, 208-218.

Oppenheimer, C. H. \& ZoBell, C. E. (1952). The growth and viability of sixty-three species of marine bacteria as influenced by hydrostatic pressure. J Mar Res 11, 10-18.

Ostle, A. G. \& Holt, J. G. (1982). Nile blue A as a fluorescent stain for poly- $\beta$-hydroxybutyrate. Appl Environ Microbiol 44, 238-241.

Perrière, G. \& Gouy, M. (1996). WWW-Query: an on-line retrieval system for biological sequence banks. Biochimie 78, 364-369.

Sawabe, T., Oda, Y., Shiomi, Y. \& Ezura, Y. (1995). Alginate degradation by bacteria isolated from the gut of sea urchins and abalones. Microb Ecol 30, 193-202.

Sawabe, T., Sugimura, I., Ohtsuka, M., Nakano, K., Tajima, K., Ezura, Y. \& Christen, R. (1998). Vibrio halioticoli sp. nov., a nonmotile alginolytic marine bacterium isolated from the gut of the abalone Haliotis discus hannai. Int J Syst Bacteriol 48, 573-580.

Sawabe, T., Thompson, F. L., Heyrman, J. \& 7 other authors (2002). Fluorescent amplified fragment length polymorphism and repetitive extragenic palindrome-PCR fingerprinting reveal hostspecific genetic diversity of Vibrio halioticoli-like strains isolated from the gut of Japanese abalone. Appl Environ Microbiol 68, $4140-4144$.

Sawabe, T., Setoguchi, N., Inoue, S., Tanaka, R., Ootsubo, M., Yoshimizu, M. \& Ezura, Y. (2003). Acetic acid production of Vibrio halioticoli from alginate: a possible role for establishment of abaloneVibrio halioticoli association. Aquaculture 219, 671-679.

Sneath, P. H. A. \& Sokal, R. R. (1973). Numerical Taxonomy: the Principles and Practice of Numerical Classification. San Francisco: Freeman.

Tamaoka, J. \& Komagata, K. (1984). Determination of DNA base composition by reverse-phase high-performance liquid chromatography. FEMS Microbiol Lett 25, 125-128.

Thompson, F. L., Hoste, B., Vandemeulebroecke, K. \& Swings, J. (2001). Genomic diversity amongst Vibrio isolates from different sources determined by fluorescent amplified fragment length polymorphism. Syst Appl Microbiol 24, 520-538.

West, M., Burdash, N. M. \& Freimuth, F. (1977). Simplified silverplating stain for flagella. J Clin Microbiol 6, 414-419. 